\title{
Study on zinc salicylate wound healing activity
}

\author{
C Sergey E. Laevsky, ${ }^{1+}$ Ksenia A. Inshakova, ${ }^{1}$ Irina S. Rakitina,${ }^{2}$ \\ Yury Yu. Byalovsky, ${ }^{2}$ Julia V. Abalenikhina, ${ }^{2}$ and Natalia V. Korotkova ${ }^{2 *}$ \\ ${ }^{1}$ Russian University of Chemical Technology Name after D.I. Mendeleev. Geroev Panfilovtsev St., 20. \\ Moscow, 125480. Russia. Phone: +7 (495) 495-24-06.E-mail: cosm-pharm@yandex.ru \\ ${ }^{2}$ Ryazan State Medical University Named after I.P. Pavlov. Vysokovoltnaya St., 9. Ryazan, 390026. Russia. \\ Phone:+7 (4912) 46-08-37.E-mail:fdpo_ryazan@mail.ru
}

Keywords: zinc salicylate, fibroblasts, regeneration, wound healing.

*Supervising author; ${ }^{+}$Corresponding author

\begin{abstract}
Acute and chronic cutaneous wounds caused by traumas, surgical interventions and a range of chronic diseases such as, for example, diabetes mellitus or chronic venous insufficiency, are widely distributed among the population all over the world, first of all among the aged patients. The treatment of acute and chronic cutaneous wounds is a current challenge for the medicine, which is not completely solved for the present day. Medicines with regenerative activity used currently have certain disadvantages, of which can be mentioned particularly the difficulties in technology and standardization of the drugs of biological origin. A range of zinc compounds (e.g., oxide, sulfate etc.) are used for a long time for the treatment of various skin diseases. Nevertheless for the present time there are some important aspects of the biological activity of zinc coordination compounds which are still not studied in detail enough, particularly the regenerative activity. In this study we investigated the regenerative activity of zinc salicylate. Zinc salicylate was prepared by reaction of an excess of zinc carbonate with salicylic acid in ethanol. Zinc salicylate activity in vitro on metabolic, proliferative and migration state of fibroblasts was investigated in cell culture. It was shown that zinc salicylate stimulates metabolic activity, increases migration state of fibroblasts, contribute to proteins adaptation to damage. Wound healing action of zinc salicylate as an active principal of a polyethyleneglycolbased ointment was studied on the model of linear wound in rats. It was shown high regenerative activity of zinc salicylate vs a standard medicine ("Levomecol").
\end{abstract}

\section{References}

[1] Wayne K. Stadelmann, M.D., Alexander G. Digenis, M.D., Gordon R. Tobin, MD, Physiology and Healing Dynamics of Chronic Cutaneous Wounds. Am J Surg. 1998; 176(Suppl 2A):26S-38S.

[2] T.V. Brailovskaya, T.A. Fedorina. Morphologic characterization of the current of wound process in experimental modeling of cut and tear-contusion wounds. Biomedicine. 2009. Iss.1. P.68-74. (russian)

[3] Sorg, H. et al. Skin wound healing: An update on the current knowledge and concepts. Eur Surg Res. 2016. Vol.58. No.1-2. P.81.

[4] F. Buchmayer, et al. Actovegin: A biological drug for more than 5 decades. Wien Med Wochenschr. 2011. Vol.161. No.3-4. P.80.

[5] Pei-Hui Lin, Matthew Sermersheim, Haichang Li, Peter H. U. Lee, Steven M. Steinberg, and Jianjie Ma. Zinc in Wound Healing Modulation. Nutrients. 2018 Jan; 10(1): 16. PMCID: PMC5793244, PMID: 29295546. doi: 10.3390/nu10010016

[6] Lansdown AB1, Mirastschijski U, Stubbs N, Scanlon E, Agren MS. Zinc in wound healing: theoretical, experimental, and clinical aspects. Wound Repair Regen. 2007 Jan-Feb;15(1):2-16. PMID: 17244314 DOI: $10.1111 / \mathrm{j} .1524-475 X .2006 .00179 . x$

[7] E.T. Lauren, A.M. Raquel, E.J. Caterson. Extracellular Matrix and Dermal Fibroblast Function in the Healing Wound. Advances in wound care. 2016. Vol.5. No.3. P.119-136.

[8] Patent 2712088 RF. MPK A61K 31/60. The medicine with a regenerative action [text]. S.E. Laevskii. 2019115213; application 17.05.2019; published 24.01.2020, Bulletin 3. 21p. (russian)

[9] Methods of investigation of cytotoxicity during the screening of medicines. Textbook to the practical studies in the course "Screening methods of the physiologically active compounds". A.G. Iksanova, O.V. Bondar, K.V. Balakin. Kazan: Kazan University. 2016. 40p. (russian) 
Full Paper_ _e.E. Laevsky, K.A. Inshakova, I.S. Rakitina, Yu.Yu. Byalovsky, Ju.V. Abalenikhina and N.V. Korotkova [10] L.G. Rodriguez, X. Wu, J.L. Guan. Wound-healing assay. Methods in Molecular Biology. 2005. 294: 23-9.doi:10.1385/1-59259-860-9:023.PMID 15576902

[11] E.R. Stadtman, R.L. Levine. Free radical-mediated oxidation of free amino acids and amino acid residues in proteins. Amino Acids. 2003. Vol.25. No.3-4. P.207-218.

[12] Mihara M, Uchiyama M. Determination of malonaldehyde precursor in tissues by thiobarbituric acid test. Anal Biochem. 1978. Vol.86. No.1. P.271-278. 